\title{
Allgemeine Literaturübersicht
}

Abramenko, Handbuch WEG, 2. Aufl., Bonn 2014

Abramenko, Das neue Wohnungseigentumsrecht, Bonn 2021

Bärmann, Kommentar zum WEG, 14. Aufl., München 2018

Bärmann/Pick, Wohnungseigentumsgesetz, 20. Aufl., München 2020

Bärmann/Seuß , Praxis des Wohnungseigentums mit Mustern und Formularen, 7. Aufl., München 2017

Belz, Handbuch des Wohnungseigentums, 3. Aufl., Stuttgart 1996

Becker/Ott/Suilmann, Wohnungseigentum, Grundlagen - Systematik - Praxis, 3. Aufl., Köln 2015

Bub, Das Finanz- und Rechnungswesen der Wohnungseigentümergemeinschaft, 3. Aufl., München 2002

Deckert/Briesemeister/Gottschlag, Die Eigentumswohnung, Loseblattsammlung, Freiburg

Dötsch/Schultzky/Zschieschack, WEG-Recht 2021, München 2021

Drasdo, Die Eigentümerversammlung nach WEG, 5. Aufl., München 2014

Drasdo, Der Verwaltungsbeirat nach dem WEG, 4.Aufl., Köln 2012

Elzer (Hrsg.), StichwortKommentar Wohnungseigentumsrecht, Baden-Baden 2021

Elzer/Hinz/Riecke/Skauradszun, Die WEG-Reform 2020/2021, Köln 2021

Greiner, Wohnungseigentumsrecht, 4. Aufl., Bonn 2017

Hogenschurz, Wohnungseigentumsgesetz, Kommentar, 3. Aufl., München 2021

Hügel/Elzer, Wohnungseigentumsgesetz, 3. Aufl., München 2021

Hügel/Scheel, Rechtshandbuch Wohnungseigentum, 4. Aufl., Münster 2018

Jennißen, Die Verwalterabrechung nach dem WEG, 7. Aufl., München 2013

Jennißen/Schmidt, Der WEG-Verwalter, 2. Aufl., München 2010

Köhler, Das neue WEG, Köln 2007

Köhler (Hrsg.), Anwalts-Handbuch Wohnungseigentumsrecht, 4. Aufl., Köln 2020

Lehmann-Richter/Wobst, WEG-Reform 2020, Köln 2020

Lutter/Hommelhoff, GmbH-Gesetz, Kommentar, 20. Aufl., Köln 2020

Lützenkirchen (Hrsg.), Anwalts-Handbuch Mietrecht, 6. Aufl., Köln 2018

Merle, Bestellung und Abberufung des Verwalters nach $₫ 26$ des Wohnungseigentumsgesetzes, Berlin 1977

Müller, Praktische Fragen des Wohnungseigentums, 6. Aufl., München 2015

Niedenführ/Schmidt-Räntsch/Vandenhouten, Handbuch und Kommentar zum WEG, 13. Aufl., Bonn 2020

Riecke/Schmid, WEG - Kommentar, 5. Aufl., Köln 2019

Röll, Teilungserklärung und Entstehung des Wohnungseigentums, Köln 1975

Röll, Handbuch für Wohnungseigentümer und Verwalter, 10. Aufl., Köln 2018

Sauren, Wohnungseigentumsgesetz, Textausgabe mit Erläuterungen, 6. Aufl., München 2014

Sauren, WEG-Verwalter, 4. Aufl., München 2009 
Spielbauer/Then, WEG, 3. Aufl., Berlin 2016

Staudinger, BGB, Band 1 und 2 zum WEG, 2005

Weitnauer, Wohnungseigentumsgesetz, Kommentar, 9. Aufl., München 2004

Zöller, Zivilprozessordnung, 33. Aufl., Köln 2020 